Hikmah: Journal of Islamic Studies, 16 (2), 2020, 219-228

http://journal.uinjkt.ac.id/index.php/HIKMAH

DOI: 10.47466/hikmah.v16i2.170 | P-ISSN. 2088-2629, E-ISSN. 2581-0146

\title{
MODERASI BERAGAMA DALAM PENDIDIKAN AGAMA ISLAM UNTUK MASYARAKAT MULTIKULTUR
}

\author{
Ahmad Faozan \\ Kementerian Agama Kabupaten Indramayu Jawa Barat \\ ahmadfaozan040979@gmail.com
}

\begin{abstract}
This article proposes the whole-school approach model, an approach to put multicultural education as strategy to involve all the stakeholders of schools in one system. Islamic education is a sub system of multicultural national education system. Religious moderation in Islamic education is a hidden curriculum, to present Islam as moderate religion, not to serve religious subject as violence and extremism. The strategy or religious moderation can be seen from some aspects, such as teacher, textbook and extra-curricular activities.
\end{abstract}

Keywords: Religious Moderation; Islamic Education; Multicultural Education

\begin{abstract}
Abstrak
Artikel ini menawarkan model whole-school approach, pendekatan yang memandang pendidikan multikultural sebagai sebuah strategi pendidikan yang melibatkan semua elemen sekolah sebagai sebuah sistem. Pendidikan Agama Islam merupakan sub sistem dari sistem pendidikan nasional yang multikultural. Moderasi beragama dalam pendidikan agama Islam dijadikan sebagai hiidden curriculum berarti cara mengajarkan pendidikan agama Islam yang moderat, bukan pendidikan agama yang mengajarkan kekerasan dan keekstreman. Strategi moderasi beragama dalam pendidikan agama Islam untuk masyarakat Indonesia multikultural dapat dilihat dari beberapa aspek antara lain guru, buku ajar dan kegiatan ekstrakurikuler.
\end{abstract}

Kata Kunci: Moderasi beragama; Pendidikan agama Islam; Pendidikan multikultural 


\section{PENDAHULUAN}

Indonesia yang multikultur merupakan blessing in disguise ${ }^{1}$ dan tidak banyak dimiliki negara bangsa lain. Ragam etnis, budaya, dan agama terdistribusi di berbagai wilayah. Kekhasan budaya dimiliki hampir setiap wilayah. Bahkan dalam satu kelompok etnis, antar sub etnis boleh jadi mempunyai logat bahasa yang berbeda, tak berbeda dengan ragam agama dan kepercayaan. Seiring dengan tingginya mobilitas dan migrasi masyarakat, pergaulan antaretnis dan agama semakin intens. Tak jarang, relasi antar etnis dan agama ini menimbulkan gesekan sosial atau bahkan kekerasan. Dalam beberapa dekade terakhir, ideologi transnasional juga turut memberi warna dalam interrelasi, antar atau intraagama dan keyakinan, damai maupun konflik. Di sinilah posisi instrumen pendidikan yang mengajarkan moderasi beragama (wasathiyah) menjadi penting. Pendidikan, termasuk pedidikan agama Islam untuk masyarakat yang multikultural bukan sekadar peningkatan pengetahuan dan pemahaman tentang nilai agama, sosial, dan budaya, namun implementasi nilai-nilai tersebut dalam kehidupan bersama, bermasyarakat, berbangsabernegara. ${ }^{2}$ Pendidikan agama Islam yang mengajarkan cara beragama yang moderat untuk masyarakat Indonesia yang multikultur.

Undang-Undang Nomor 20 Tahun 2003 tentang Sistem Pendidikan Nasional memberikan pijakan untuk menerapkan pendidikan (agama Islam) yang mengajarkan moderasi beragama. Pasal 4 ayat 1 menyuratkan bahwa "Pendidikan diselenggarakan secara demokratis dan berkeadilan serta tidak diskriminatif dengan menjunjung tinggi hak asasi manusia, nilai keagamaan, nilai kultural, dan kemajemukan bangsa.” Lebih lanjut pasal 5 mengatakan bahwa setiap warga negara berhak mendapatkan pendidikan berkualitas. Ini menunjukkan bahwa tidak ada diskriminasi di antara warga negara untuk memperoleh pendidikan berkualitas tanpa memandang status sosial dan ekonomi mereka. Proses pendidikan pun harus dapat membantu warga negara untuk mengembangkan sikap dan nilai-nilai kejujuran, keadilan, persamaan dan penghargaan atas perbedaan.

Pijakan pelaksanaan pendidikan multikultural ini belum termanifestasi dalam kebijakan-kebijakan pendidikan. Visi pendidikan tidak secara jelas menyebutkan bahwa pendidikan Indonesia berorientasi pada multikultural. ${ }^{3}$ Penelitian Raihani menemukan bahwa pendidikan multikultural dikembangkan dan dilaksanakan di Indonesia tidak secara sistematis dan sadar sebagai program dan strategi yang inheren dalam pendidikan

${ }^{1}$ Azyumardi Azra, Merawat Kemajemukan Merawat Indonesia, Seri Orasi Budaya, (Yogyakarta: Penerbit Impulse, 2007), 5.

${ }^{2}$ Azyumardi Azra, Merawat Kemajemukan Merawat Indonesia, 22. Muhammad Tholchah Hasan, Pendidikan Multikultural sebagai Opsi Penanggulangan Radikalisme, (Malang: Lembaga Penerbitan Unisma, 2016). Dede Rosyada, Pendidikan Multikultural Melalui Pendidikan Agama: Gagasan Konsepsional, dalam Madrasah dan Profesionalisme Guru dalam arus Dinamika Pendidikan Islam di Era Otonomi Daerah, (Jakarta: Penerbit Kencana, 2017), 317-333. Choirul Mahfud, Pendidikan Multikultural, (Yogyakarta: Pustaka Pelajar, 2016).

${ }^{3}$ Raihani, Pendidikan Islam dalam Masyarakat Multikultural, (Yogyakarta: Penerbit Pustaka Pelajar, 2019), Cet. II, 146. 
Indonesia. Pendidikan multikultural dilaksanakan secara sporadis, tanpa desain dan visi yang jelas. Pesan pendidikan yang menghargai perbedaan dan keragaman dalam undangundang sistem pendidikan nasional tidak diejawantahkan secara konsisten dalam kebijakan di bawahnya dan proses pendidikan di sekolah. ${ }^{4}$

Dalam konteks pendidikan agama Islam, beberapa penelitian lain menemukan bahwa infiltrasi paham dan gerakan transnasional mulai merambah ke sekolah dan universitas sebagai instrumen penting dalam pembangunan peradaban bangsa. Paham dan gerakan transnasional masuk ke lembaga pendidikan melalui buku teks ${ }^{5}$ alumni yang berafiliasi dengan gerakan radikal, ${ }^{6}$ dan kegiatan ekstrakurikuler. ${ }^{7}$

Kondisi ini diperparah dengan sebagian guru agama yang memiliki pandangan cenderung eksklusif dan radikal. Temuan penelitian Pusat Pengkajian Islam dan Masyarakat (PPIM) UIN Syarif Hidayatullah Jakarta pada 2016 ini memberikan gambaran bahwa pandangan keagamaan guru-guru PAI berpotensi mengancam keragaman bangsa Indonesia yang plural. ${ }^{8}$

Temuan PPIM UIN Syarif Hidayatullah Jakarta diperkuat dengan survey yang dilakukan Convey Indonesia pada 2018 tentang opini/sikap dan aksi/perilaku keberagamaan guru dan dosen dengan melihat tingkat radikalisme dan intoleransi mereka. Hasil survey memperlihatkan sebagian besar guru dan dosen memiliki sikap keberagamaan yang moderat $(52,5 \%)$ dan toleran $(45,3 \%$ toleransi terhadap umat agama lain atau toleransi eksternal, dan 54\% toleransi terhadap penganut aliran atau kelompok yang berbeda di dalam internal umat Islam atau toleransi internal). Seperti dalam level sikap, guru dan dosen juga cenderung memiliki perilaku, pada level tindakan, yang cenderung moderat $(74,2 \%)$ dan toleran secara internal $(61,5 \%)$. Tetapi, para guru dan dosen tampak intoleran $(69,3 \%)$ jika dilihat dari perilaku toleransi internal. Tingkat intoleransi internal yang tinggi memiliki korelasi dengan penolakan atau stigma negatif mereka terhadap kelompok aliran yang dianggap menyimpang atau sesat di dalam umat Islam, terutama kepada penganut Syiah dan Ahmadiyah. Berdasarkan data, guru dan dosen sebanyak

\footnotetext{
${ }^{4}$ R. Raihani, Education for Multicultural Citizens in Indonesia: Policies and Practices, dalam Compare: A Journal of Comparative and International Education, 2017, DOI: 10.1080/03057925.2017.1399250.

${ }^{5}$ Hamid Nasuhi, dkk. Intoleransi dalam Buku Pendidikan Islam: Telaah atas Isi dan Kebijakan Produksi, (Jakarta: PPIM UIN Syarif Hidayatulah dan Prenadamedia, 2018).

${ }^{6}$ Bano Masooda, Didin Syafruddin, Azyumardi Azra, Abuddin Nata, Rusydy Zakaria, dan Suparto Sunoko, Study on Islamic Religious Education in Secondary Schools in Indonesia, (Jakarta: Directorate of Islamic Education Ministry of Religious Affair, Republic of Indonesia Kemenag RI, 2016).

${ }^{7}$ Abdul Azis Muslim, dkk. Menjaga Benteng Kebinekaan di Sekolah: Studi Kebijakan OSIS di Kota Padang, Kab. Cirebon, Kab. Sukabumi, Kota Surakarta, Kota Denpasar dan Kota Tomohon, (Jakarta: Maárif Institue, 2018).

${ }^{8}$ Didin Syafruddin, dkk, Potret Guru Agama: Pandangan tentang Toleransi dan Isu-Isu Kehidupan Keagamaan, (Jakarta: PPIM UIN Syarif Hidayatulah dan Prenadamedia, 2018).
} 
87,89\% menyatakan setuju jika pemerintah melarang keberadaan kelompok-kelompok minoritas yang dianggap menyimpang dari ajaran Islam. ${ }^{9}$

Penelitian CISForm UIN Sunan Kalijaga Yogyakarta tentang sistem produksi guru pendidikan agama Islam (PAI) di Indonesia juga menemukan bahwa 1) Input dan rekrutmen calon mahasiswa PAI masih memberikan peluang bagi lulusan SMA/SMK umum yang notabene mempunyai keterbatasan keilmuan agama Islam dibanding memberikan peluang lebih besar bagi lulusan-lulusan MA atau SMA Islam/pesantren, 2) Program studi PAI lembaga pendidikan tenaga kependidikan cenderung hanya merespons kebutuhan pasar untuk mencetak guru agama SD, SMP, dan SMA, dibanding merespons isu-isu agama (Islam) aktual-kontemporer. Kurikulum prodi PAI yang lebih banyak menekankan pada kompetensi pedagogis daripada kompetensi profesional keislaman. Ditambah lagi, kurikulum kompetensi profesional Prodi PAI juga tidk memberi peluang lebih pada mata kuliah aktual-kontemporer dan pembelajaran kritis, 3) Dalam proses pembelajaran, sebagian dosen PAI mempunyai kompetensi bahasa Arab yang rendah dan sikap keberagamaan yang cenderung intoleran dan eksklusif, 4) Dalam proses pembelajaran juga ditemukan bahwa kompetensi bahasa Arab mahasiswa relatif rendah dan pandangan keagamaan yang berpotensi mengarah pada intoleran dan radikal. Walaupun kompetensi bahasa Arab rendah tidak secara langsung berpotensi mengarah pada intoleran, namun akan membatasi mahasiswa mengakses sumber-sumber keislaman yang primer dan otoritatif, 5) Kegiatan-kegiatan ekstra kampus hingga lingkungan kampus, seperti LDK dan pesantren memiliki peran signifikan dalam membentuk pemahaman dan sikap keagamaan mahasiswa calon guru PAI. Bukti konkrit menguatnya islamisme dalam kegiatan ekstra kampus ditunjukkan dengan semakin banyaknya mahasiswi bercadar di LPTK, 6) Beberapa program keagamaan tambahan seperti baca tulis Al-Quran (BTQ), bahasa Arab, qiraatul kutub, tahfidz, pesantren kilat, pengajian-pengajian di kampus yang bersifat instan dikhawatirkan justru kurang mengajarkan Islam yang komprehensif dan cara berpikir kritis dalam beragama serta akan mendorong munculnya konservatisme, dan 7) Secara umum, kompetensi lulusan Prodi PAI di LPTK 'hanya' sesuai untuk menjadi guru PAI di sekolah umum, bukan diperuntukkan bagi madrasah atau sekolah Islam. ${ }^{10}$

Terkait kegiatan ekstrakurikuler, hasil penelitian dari PPIM tahun 2017 yang menyoal sikap keberagaman generasi $Z$. Jumlah responden survey nasional ini adalah 2.181 orang yang terdiri dari 1.522 siswa, 337 mahasiswa, 264 guru dan 58 dosen. Hasilnya menunjukkan pada tingkat opini siswa atau mahasiswa, $51.1 \%$ pemahaman mereka intoleran dan 58.5\% pemahaman mereka radikal. Sementara dalam sikap, aksi intoleransi mereka $34.1 \%$ dan aksi radikalnya $7.0 \%$. Survey ini juga melihat bagaimana generasi $\mathrm{Z}$

\footnotetext{
${ }^{9}$ Rangga Eka Saputra, Convey Report: Sikap dan Perilaku Keberagamaan Guru dan Dosen Pendidikan Agama Islam, Vol 1 Nomor 8 Tahun 2018, (Jakarta: PPIM UIN Syarif Hidayatulah, 2018)

${ }^{10}$ Muhammad Wildan, dkk, Menanam Benih di Ladang Tandus: Potret Sistem Produksi Guru Agama Islam di Indonesia, (Yogyakarta: CISForm UIN Sunan Kalijaga, 2019).
} 
mendapatkan informasi mengenai ajaran agama Islam. Hasilnya, 54.87\% mereka mengakses internet. Sejumlah faktor ditengarai menjadi penyebab yang menyumbangkan tumbuhnya kecenderungan pandangan keagamaan yang intoleran dan radikal di atas ini. Salah satu yang paling langsung adalah tidak adanya dorongan untuk menggunakan perangkat kelembagaan sekolah, khususnya peran OSIS-untuk melibatkan diri dalam upaya-upaya yang sistematis dan berkelanjutan untuk membendung radikalisme di sekolah. Di samping itu, melalui kekuatan kelembagaan tadi dan program-program kreatif yang diciptakan, sekolah juga belum terdorong untuk mengimplementasikan sejumlah kebijakan tentang OSIS yang boleh jadi sangat efektif menangkal bahaya radikalisme dan intoleransi di internal sekolah. ${ }^{11}$ Penelitian lain juga menemukan satu fenomena umum di internal sekolah, yakni masih rendahnya inisiasi pemangku kebijakan sekolah dalam merumuskan kebijakan khusus dalam upaya menghadang radikalisme di sekolah. Di beberapa sekolah, tentu sudah ada upaya yang mengarah kepada hal tersebut, namun upaya tersebut jauh tidak berimbang dengan massifnya gerakan radikal yang masuk ke sekolah. ${ }^{12}$

Berdasarkan larat belakang masalah di atas, teridentifikasi beberapa permasalahan dalam tulisan ini, yaitu adanya kesenjangan antara kondisi ideal pendidikan multikultural dalam undang-undang sistem pendidikan nasional dengan realitas pelaksanaan pendidikan multikultural, ancaman infiltrasi paham dan gerakan transnasional yang mulai merasuk ke buku ajar, alumni dan kegiatan ekstrakurikuler, sikap dan perilaku keagamaan guru dan dosen yang cenderung intoleran serta sistem produksi guru pendidikan agama Islam di Indonesia yang memberi peluang munculnya paham keagamaan radikal. Dengan demikian, pendidikan agama Islam membutuhkan sebuah model atau strategi untuk masyarakat multikultural yang khas Indonesia. Merujuk pada latar belakang masalah dan identifikasi masalah di atas, rumusan masalah pada tulisan ini adalah "bagaimana model atau strategi pendidikan agama Islam untuk masyarakat multikultural yang khas Indonesia?”

\section{METODE}

Jenis data yang digunakan dalam penelitian ini adalah ungkapan- ungkapan atau pernyataan, baik tertulis maupun lisan. Sumber data utama berupa dokumen berita dan teks narasi penguatan moderasi beragama masyarakat multikultural di Indonesia. Metode pengumpulan data yang digunakan adalah library research dengan teknik note-taking. Adapun teknis analisis data yang digunakan adalah deskriptif-analitik.

\footnotetext{
${ }^{11}$ Abdul Azis Muslim, dkk. Menjaga Benteng Kebinekaan di Sekolah, vii.

${ }^{12}$ Abdul Azis Muslim, dkk. Menjaga Benteng Kebinekaan di Sekolah, vii.
} 


\section{PEMBAHASAN}

\section{Strategi Pemecahan Masalah}

Secara umum, terdapat dua pendekatan besar dalam pendidikan multikultural, yaitu curricular approach dan whole-school approach. ${ }^{13}$ Curricular approach merupakan sebuah pendekatan yang memberi penekanan penting pada pemuatan knowledge dan values dari keberagaman dan bagaimana membentuk perspektif terhadap keberagaman. Mendukung pendekatan kurikulum ini, Bikhu Parekh (2006) -dalam Raihani, ${ }^{14}$ yang menyatakan bahwa dalam mengembangkan pendidikan multikultural, hal yang paling utama adalah mereformasi isi kurikulum yang mampu mendukung para siswa untuk memiliki sikap menghargai sebagai sebuah keniscayaan. Biasanya dalam pendekatan ini, konsep dan kenyataan perbedaan masyarakat dan multikulturalisme dimasukkan ke dalam disiplindisiplin ilmu sosial dan humaniora. Cara memasukkan konsep dan kenyataan multikulturalisme ini disebut infusion. Salah satu kelemahan infusion ialah mudah terperangkap dalam insersi superfisial, yaitu penyelipan nilai-nilai multikultural tanpa melakukan perubahan substansial terhadap kurikulum. Hal ini dapat menimbukan kontradiksi dan kebingungan dalam kurikulum yang berakibat pesan dari nilai-nilia multikultural dapat terganggu.

Sedangkan pendekatan whole-school approach memandang pendidikan multikultural sebagai sebuah strategi pendidikan yang melibatkan semua elemen sekolah sebagai sebuah sistem. Asumsi pendekatan ini bahwa pendidikan multikultural sebagai pendidikan nilai tidak dapat dilakukan secara parsial. Halstead (1996) menyatakan tidak bisa menganggap remeh pengalaman-pengalaman non-classroom yang tidak menjadi bagian dari kurikulum formal dalam pembentukan watak dan perilaku anak. ${ }^{15}$ Banks menyatakan bahwa "multicultural education views the school as a social system that consists of highly interrelated parts and variables." Artinya pendidikan multikultural memandang sekolah sebagai sistem sosial yang terdiri dari bagian dan variabel yang sangat saling terkait.

Raihani mengembangkan model pendidikan multikultural untuk konteks Indonesia berdasarkan hasil penelitiannya. Menurutnya, model pendidikan multikultural mempertimbangkan tiga faktor utama dalam pendidikan multikultural yaitu kondisi masyarakat Indonesia yang multireligius dan multietnik, kebijakan pendidikan nasional dan pengetahuan, nilai dan keterampilan pelaku pendidikan. Model ini bertumpu pada visi

${ }^{13}$ Raihani, Pendidikan Islam dalam Masyarakat Multikultural, 143. Lihat juga Syafiq A. Mughni, Pendidikan Berbasis Multikulturalisme, dalam Choirul Mahfud, Pendidikan Multikultural, (Yogyakarta: Pustaka Pelajar, 2016), Cet. VIII, ix-x.

${ }^{14}$ Raihani, Pendidikan Islam dalam Masyarakat Multikultural, 143.

${ }^{15}$ J. Mark Halstead, Values and Values Education in Schools, in J. Mark Halstead and Monica J. Taylor (ed), Values in Education and Education in Values, (London, The Falmer Press, 1996), 3-14.

${ }^{16}$ James A. Banks, Multicultural Education: Characteristics and Goals, in James A. Banks and Cherrya.McGee Banks (ed), Multicultural Education Issues and Perspectives, Seventh Edition, (New Jersey: Wiley, 2010), 3-30. 
dan kebijakan sekolah yang secara jelas dan tegas menjadikan pendidikan multikultural sebagai inti, kurikulum ilmu-ilmu sosial dan humaniora yang memiliki muatan multikultural dan pedagogik yang memberi kesempatan bagi semua peserta didik untuk berkembang di semua disiplin, budaya sekolah yang menghormati keberagaman dan keadilan sosial, kegiatan ekstrakurikuler yang eksposur terhadap perbedaan dan menumbuhkan solidaritas lintas batas serta kepemimpinan dan manajemen yang demokratis partisipatif. ${ }^{17}$ Dengan demikian, model pendidikan multikultural yang lebih mumpuni adalah pendidikan multikultural yang menggunakan whole-school approach.

Dalam konteks pendidikan agama Islam (PAI), PAI merupakan bagian tak terpisahkan dari pendidikan multikultural dengan whole-school approach. PAI tidak dapat berdiri sendiri untuk mengajarkan cara beragama yang moderat, namun menjadi sub sistem dari sistem pendidikan nasional yang multikultural. Kementerian Agama sebagai pelaksana pengelolaan pendidikan agama mencanangkan tahun 2019 sebagai "Tahun Moderasi Beragama Kementerian Agama.” Moderasi Beragama, menurut Menteri Agama, harus menjadi jiwa institusi Kementerian Agama, yang sepanjang keberadaannya akan terus mendapat amanah untuk mengelola kehidupan keagamaan di Indonesia. ${ }^{18}$ Tentu upaya kementerian agama ini menjadi tumpuan bagi berkembangnya moderasi beragama dalam pendidikan agama Islam.

Moderasi dalam bahasa Inggris "moderation" berarti 1) the quality of being moderate; restraint; avoidance of extremes or excesses; temperance. 2) the act of moderating. ${ }^{19}$ Moderasi berarti 1) kualitas menjadi moderat; pengendalian; menghindari ekstrem atau ekses; kesederhanaan. 2) Tindakan memoderasi. Sementara dalam KBBI, moderasi mengandung dua arti yaitu 1) pengurangan kekerasan dan 2) penghindaran keekstreman. $^{20}$

Moderasi beragama dalam pendidikan agama Islam berarti cara mengajarkan pendidikan agama Islam yang moderat, bukan pendidikan agama yang mengajarkan kekerasan dan keekstreman. Beberapa strategi moderasi beragama dalam pendidikan agama Islam untuk masyarakat Indonesia multikultural dapat dilihat dari beberapa aspek. Tulisan ini menyoroti pada tiga hal sesuai dengan beberapa hasil riset di atas antara lain guru, buku ajar dan kegiatan ekstrakurikuler.

1. Aspek Guru

Dalam penelitian PPIM UIN Jakarta tahun 2016, ditemukan bahwa guru-guru yang memiliki wawasan yang luas tentang keislaman dan kebangsaan adalah guru-

\footnotetext{
${ }^{17}$ Raihani, Model Pendidikan Multikultural untuk Indonesia dalam Pendidikan Islam dalam Masyarakat Multikultural, 153-156.

${ }^{18}$ Lukman Hakim Saifuddin, Moderasi untuk Kebersamaan Umat: Memaknai Rapat Kerja Nasional Kemenag 2019, file pdf.

${ }^{19}$ https://www.dictionary.com/browse/moderation?s=t, diunduh pada 27/09/2019.

${ }^{20}$ https://kbbi.kemdikbud.go.id/entri/moderasi, diunduh pada 27/09/2019.
} 
guru yang memiliki basic pendidikan pesantren atau yang memiliki modal studi keislaman yang kuat. Dengan demikian, untuk meningkatkan kompetensi guru PAI, pemerintah perlu membenahi sistem rekrutmen dan seleksi guru PAI yang memiliki kompetensi profesional tentang studi Islam dan wawasan kebangsaan yang kuat. ${ }^{21}$ Sistem produksi guru PAI di Fakultas Tarbiyah juga perlu mempromosikan keselarasan yang mendukung kompetensi profesional tentang studi Islam dan wawasan kebangsaan yang kuat. ${ }^{22}$ Sementara bagi guru PAI yang sudah diangkat menjadi PNS, Prof. Dr. Azyumardi Azra menyebutkan untuk diselenggarakan pelatihan guru agama wajib bela negara. ${ }^{23}$

2. Aspek Buku Ajar

Buku teks PAI merupakan buku yang wajib dimiliki oleh seluruh siswa di sekolah. Untuk mendukung moderasi beragama dalam pendidikan agama Islam, perlu pengembangan buku ajar, buku pengayaan dan buku guru yang memperkuat wawasan keislaman dan keindonesiaan serta dapat tersedia secara elektronik dan mudah diakses oleh guru PAI. ${ }^{24}$

3. Kegiatan Ekstrakurikuler

Terkait kegiatan ekstrakurikuler, dalam riset ditemukan beberapa praktik terbaik, misalnya di Cirebon, dengan menggandeng komunitas atau kelompok lain yang concern pada isu-isu keislaman dan kebangsaan, melalui kegiatan pendampingan dan deklarasi organisasi pelajar damai, melakukan kunjungan ke komunitas berbeda atau sejumlah tempat ibadah agama lain, dan karnaval kebinekaan. ${ }^{25}$

\section{PENUTUP}

Model pendidikan multikultural untuk masyarakat multikultural seperti Indonesia mempertimbangkan tiga faktor utama dalam pendidikan multikultural yaitu kondisi masyarakat Indonesia yang multireligius dan multietnik, kebijakan pendidikan nasional dan pengetahuan, nilai dan keterampilan pelaku pendidikan. Model ini menggunakan whole-school approach, pendekatan yang memandang pendidikan multikultural sebagai sebuah strategi pendidikan yang melibatkan semua elemen sekolah sebagai sebuah sistem.

\footnotetext{
${ }^{21}$ Didin Syafruddin, dkk, Potret Guru Agama, 374.

${ }^{22}$ Rangga Eka Saputra, Convey Report: Sikap dan Perilaku Keberagamaan Guru dan Dosen Pendidikan Agama Islam, .., Didin Syafruddin, dkk, Potret Guru Agama, 374.

${ }^{23}$ Prof. Dr. Azyumardi Azra, Catatan Perkuliahan pada Mata Kuliah Contemporary Islamic World pada Program Doktor Sekolah Pascasarjana UIN Syarif Hidayatullah Jakarta, 2018.

${ }^{24}$ Didin Syafruddin, dkk, Potret Guru Agama, 374.lihat juga Hamid Nasuhi, dkk. Intoleransi dalam Buku Pendidikan Islam.

${ }^{25}$ Abdul Azis Muslim, dkk. Menjaga Benteng Kebinekaan di Sekolah, vii.
} 
Pendidikan Agama Islam menjadi sub sistem dari sistem pendidikan nasional yang multikultural. Moderasi beragama dalam pendidikan agama Islam berarti cara mengajarkan pendidikan agama Islam yang moderat, bukan pendidikan agama yang mengajarkan kekerasan dan keekstreman.

Strategi moderasi beragama dalam pendidikan agama Islam untuk masyarakat Indonesia multikultural dapat dilihat dari beberapa aspek antara lain guru, buku ajar dan kegiatan ekstrakurikuler. Pemerintah c.q. Direktorat Pendidikan Agama Islam Direktorat Jenderal Pendidikan Islam Kementerian Agama RI perlu membenahi beberapa hal, antara lain: a) sistem rekrutmen dan seleksi guru PAI yang memiliki kompetensi profesional tentang studi Islam dan wawasan kebangsaan yang kuat, b) mempertinggi penyelenggaraan pelatihan guru agama wajib bela negara, dan c) pengembangan buku ajar, buku pengayaan dan buku guru yang memperkuat wawasan keislaman dan keindonesiaan serta dapat tersedia secara elektronik dan mudah diakses oleh guru PAI.

Perguruan Tinggi Keagamaan Islam yang menyeleggarakan sistem produksi guru PAI di Fakultas Tarbiyah juga perlu mempromosikan keselarasan yang mendukung kompetensi profesional tentang studi Islam dan wawasan kebangsaan yang kuat. Sekolah yang menyelenggarakan kegiatan ekstrakurikuler, dapat menggandeng komunitas atau kelompok lain yang concern pada isu-isu keislaman dan kebangsaan, melalui kegiatan pendampingan dan deklarasi organisasi pelajar damai, melakukan kunjungan ke komunitas berbeda atau sejumlah tempat ibadah agama lain, dan karnaval kebinekaan.

\section{DAFTAR PUSTAKA}

Azra, Azyumardi, Catatan Perkuliahan pada Mata Kuliah Contemporary Islamic World pada Program Doktor Sekolah Pascasarjana UIN Syarif Hidayatullah Jakarta, 2018.

Azra, Azyumardi, Merawat Kemajemukan Merawat Indonesia, Seri Orasi Budaya, (Yogyakarta: Penerbit Impulse, 2007).

Banks, James A., Multicultural Education: Characteristics and Goals, in James A. Banks and Cherrya.McGee Banks (ed), Multicultural Education Issues and Perspectives, Seventh Edition, (New Jersey: Wiley, 2010).

Halstead, J. Mark, Values and Values Education in Schools, in J. Mark Halstead and Monica J. Taylor (ed), Values in Education and Education in Values, (London, The Falmer Press, 1996).

Hasan, Muhammad Tholchah, Pendidikan Multikultural sebagai Opsi Penanggulangan Radikalisme, (Malang: Lembaga Penerbitan Unisma, 2016).

https://kbbi.kemdikbud.go.id/entri/moderasi, diunduh pada 27/09/2019.

https:/www.dictionary.com/browse/moderation?s=t, diunduh pada 27/09/2019.

Mahfud, Choirul, Pendidikan Multikultural, (Yogyakarta: Pustaka Pelajar, 2016). 
Masooda, Bano., Didin, Syafruddin., Azra, Azyumardi., Nata, Abuddin., Zakaria, Rusydy., dan Sunoko, Suparto. Study on Islamic Religious Education in Secondary Schools in Indonesia, (Jakarta: Directorate of Islamic Education Ministry of Religious Affair, Republic of Indonesia Kemenag RI, 2016).

Mughni, Syafiq A., Pendidikan Berbasis Multikulturalisme, dalam Choirul Mahfud, Pendidikan Multikultural, (Yogyakarta: Pustaka Pelajar, 2016), Cet. VIII.

Muslim, Abdul Azis, dkk. Menjaga Benteng Kebinekaan di Sekolah: Studi Kebijakan OSIS di Kota Padang, Kab. Cirebon, Kab. Sukabumi, Kota Surakarta, Kota Denpasar dan Kota Tomohon, (Jakarta: Maárif Institue, 2018).

Nasuhi, Hamid, dkk. Intoleransi dalam Buku Pendidikan Islam: Telaah atas Isi dan Kebijakan Produksi, (Jakarta: PPIM UIN Syarif Hidayatulah dan Prenadamedia, 2018).

R. Raihani, Education for Multicultural Citizens in Indonesia: Policies and Practices, dalam Compare: A Journal of Comparative and International Education, 2017, DOI: $10.1080 / 03057925.2017 .1399250$.

Raihani, Pendidikan Islam dalam Masyarakat Multikultural, (Yogyakarta: Penerbit Pustaka Pelajar, 2019), Cet. II.

Rosyada, Dede, Pendidikan Multikultural Melalui Pendidikan Agama: Gagasan Konsepsional, dalam Madrasah dan Profesionalisme Guru dalam arus Dinamika Pendidikan Islam di Era Otonomi Daerah, (Jakarta: Penerbit Kencana, 2017)

Saifuddin, Lukman Hakim, Moderasi untuk Kebersamaan Umat: Memaknai Rapat Kerja Nasional Kemenag 2019.

Saputra, Rangga Eka, Convey Report: Sikap dan Perilaku Keberagamaan Guru dan Dosen Pendidikan Agama Islam, Vol 1 Nomor 8 Tahun 2018, (Jakarta: PPIM UIN Syarif Hidayatulah, 2018)

Syafruddin, Didin, dkk, Potret Guru Agama: Pandangan tentang Toleransi dan Isu-Isu Kehidupan Keagamaan, (Jakarta: PPIM UIN Syarif Hidayatulah dan Prenadamedia, 2018).

Wildan, Muhammad, dkk, Menanam Benih di Ladang Tandus: Potret Sistem Produksi Guru Agama Islam di Indonesia, (Yogyakarta: CISForm UIN Sunan Kalijaga, 2019). 